\title{
A Definition of Folklore: A Personal Narrative
}

\author{
Dan Ben-Amos \\ University of Pennsylvania \\ dbamos@sas.upenn.edu
}

\begin{abstract}
My definition of folklore as "artistic communication in small groups" was forged in the context of folklore studies in the I960s, in the discontent with the definitions that were current at the time, and under the influence of anthropology, linguistics - particularly 'the ethnography of speaking' - and Russian formalism. My field research among the Edo people of Nigeria had a formative impact upon my conception of folklore, when I observed their storytellers, singers, dancers and diviners in performance. The response to the definition was initially negative, or at best ambivalent, but as time passed, it took a more positive turn.
\end{abstract}

KEYWORDS

context; communication; definition; performance; process

\section{RESUM}

La meva definició de folklore com a "comunicació artística en petit grup» va sorgir en el context dels estudis folklòrics dels anys seixanta, com a resultat de la meva insatisfacció amb les definicions que circulaven en aquell moment, i sota la influència de l'antropologia, la lingüística -en particular 〈l'etnografia de la parla〉-i el formalisme rus. El meu treball de camp entre els habitants d'Edo a Nigèria va tenir un impacte formatiu en la meva concepció del folklore, quan vaig observar els seus narradors, cantants, ballarins i endevins en acció. La resposta a la definició va ser inicialment negativa o, en el millor dels casos, ambivalent, però a mesura que passava el temps, va prendre un gir més positiu.

PARAUles Clau

context; comunicació; definició; performance; procés 
When Professor CARMe Oriol invited me to the conference honoring the memory of the late Professor Josep M. Pujol (I947-2OI2), I first politely declined.

"I have not read his work, except for his masterful folktale index of Catalan folktales that both of you edited," I told her, "I really am not familiar with his scholarship."

"You could not have been," she replied, "unless you knew Catalan, because he wrote exclusively in Catalan. ${ }^{2}$ But," she added "he knew your work." And later she sent me a copy of her, then forthcoming, obituary for Professor Pujol (Oriol 20I2) in which she pointed out that he was influenced by the works of my teacher, Professor Richard M. Dorson (I9I6-I98I), and by my own definition of folklore. At that moment I felt embarrassed and sad. Embarrassed, because of the lack of mutuality in our relation. He knew my work, but I did not know his. Sad, because we could not meet and I could not tell him the story of my definition of folklore, nor discuss it with him, refine my own conception of folklore and benefit from his erudite comments and analytical insights. But this was not to be. I can only tell the story of my definition of folklore to you, his students and colleagues, as a personal narrative, from a perspective that a period of 46 years allows.

The number of years that I have just mentioned holds its own narrative episode.

My essay "Toward a Definition of Folklore in Context" was published in the Journal of American Folklore in I97I (Ben-Amos I97I), but it had been written four years earlier in I967. What prompted me to write a new definition of folklore was an invitation from a publisher to write an introductory textbook for folklore, and when I started to do so, I thought I would begin - where else? - at the beginning, and define the book's subject. Someone on the various committees and editorial boards of the publishing house had a brilliant idea. More often than not, introductory textbooks were written by senior scholars in their respective academic disciplines: senior professors, experienced teachers and accomplished researchers. However, as Thomas Kuhn has acutely observed, these "textbooks were pedagogical vehicles for the perpetuation of normal science" (Kuhn I962: I37-I38). They presented linear histories of their respective disciplines, beginning at the formative stages of the currently dominant scientific paradigm. These introductory textbooks inherently suffered from three basic shortcomings: they ignored "the historical integrity of that science in its own time" (Kuhn

I. Oriol-Pujol (2008).

2. Subsequent to our conversation three essays of the late Josep M. Pujol appeared in English translation as Three Selected Papers on Catalan Folklore (Pujol 20I3.) The volume includes "Folkloric Bibliography of Josep M. Pujol" (2013: 65-69.) A compilation of his essays in Catalan is edited by Carme Oriol and Emili Samper (2013). 
I962: 3); their historical narratives were, to use a term proposed by George W. Stocking (I965), "presentist"; and they validated and reaffirmed "the normal science' of their respective disciplines, rather than the agitation that permeated among younger scholars and which was likely to be symptomatic of future trends in scholarship. Reversing the process, somebody apparently proposed to commission young professionals, fresh out of graduate schools, who by their very position and learning trajectory would address the current and future theories and methods of their respective disciplines. The publisher set out to scout for potential writers in different disciplines, across the academic spectrum, and in spite of its limited presence in American universities, decided to include the discipline of folklore in this projected series of future-oriented introductions.

I did not know then, and do not know until this very day, who suggested to the publisher's author scout to contact me. At that time, I had but a few publications: three short articles that appeared, one each, in Switzerland (Ben-Amos I963a), India (Ben-Amos 1963b), and Nigeria (Ben-Amos I967a); and two in the United States (Ben-Amos I963c; I967b). And I had been credited for assisting my teacher at the Hebrew University, Professor Dov Noy, to edit the volume of Folktales of Israel (Ben-Amos I967b). None of these publications could have indicated to any publisher that I was the potential author of a future-oriented textbook on folklore. In retrospect I would credit my friends and teachers for directing that agent to me; either they did not want to write such a textbook themselves, or they thought that I could. At any rate, I had the audacity to accept the offer nonchalantly, taking for granted that I could and would accomplish the task.

The year was I967. I started teaching at a university during the academic year of I966-I967, having a one year renewable appointment at the Anthropology Department of the University of California, Los Angeles (UCLA). At that time I had just returned to the United States, after an eight-month period of field work among the Edo people of Midwestern Nigeria (Bendel State). I arrived in Nigeria on I5 January I966, the day of the first military coup d'etat, ${ }^{3}$ and returned to the United States in late August 1966.

Upon my return, I assumed a teaching position at the Department of Anthropology of the University of California, Los Angeles (UCLA), and maintained close personal and academic association with both the newly established African Studies Center, and the by then internationally renowned Folklore and Mythology Center, which was headed by Professor Wayland Hand (I907-I986) and counted among its members such distinguished scholars as D.K. Wilgus (I9I8-I989), Donald Ward (I927-I990), Sam Armistead (I927-2013), Jaan Puhvel, and Robert Georges.

That was also the first year that the American Folklore Society had its own independent annual meeting. Until then, it had alternated its annual meetings between the Modern Language Association and the American Anthropological

3. This was an obvious milestone in Nigerian history, but upon arrival at the Lagos airport
I experienced it as a colossal nuisance. For historical studies and analyses of the I5 January
Nigerian coup d'etat see: Richard Akinnola (I998: I-7); Adewale Ademoyega (I98I); R.
Luckham (I97I: I7-5O); L. A. Nwachuku and G. N. Uzoigwe (2004: 32-38); A. Nwankwo
(I987: 97-I24); John Oyinbo (I97I: 36-80); A. Arthur (I987: 97-I24); S. K. Panter-Brick (I970). 
Association. ${ }^{4}$ When the call for paper proposals for the meeting was issued, I was in Nigeria, meeting storytellers and singers and attending rituals at the local shrines of the Edo gods. Annual scholarly meetings could not have been farther from my mind. Therefore, without a lecture scheduled on the program, I had to sit out that historical annual meeting of the American Folklore Society convened in Boston.

But when the call for paper proposals for the 1967 meeting was issued, I was eager to participate. By that time I had already had my meeting with the publisher's literary agent, and might even have signed a book contract. I thought that the first chapter of that projected book would be an appropriate subject for a conference lecture and I sent in my proposal which I titled "Folklore: The Definition Game Once Again".

I did not mean to undermine the significance of my own definition of folklore, then only vaguely verbalized, nor was the usage of such a title a rhetorical ploy that the psychoanalyst Martin Grotjahn (I904-I990) diagnosed as a distinctive feature of Jewish humor: namely, self-criticism that would deflect anticipated critical comments by others (Grojahn I966). Neither was the title a strategy intended to disarm any objections by responding: "This is only a game".

Rather, by the mid-sixties of the $2 \mathrm{O}^{\text {th }}$ century, the discipline of folklore was inundated with definitions and redefinitions that hampered research and obscured, rather than clarified, its boundaries, identity, subject matter, and research goals. Twenty years earlier, as folklorists around the world celebrated the centennial of William Thoms' (I803-I885) coinage of the term "Folk-Lore",5 its reassessment and re-evaluation was in full force. The respective presidential addresses of Melville Herskovits (I895-I963), ${ }^{6}$ then president of the American Folklore Society (Herskovits I946), and Lord Raglan (I885-I964), then president of the Folklore Society in England (Raglan I946), were concerned with the indefiniteness of folklore, or the inertness of the discipline that the term had initiated.

As the title of his lecture indicated, Herskovits proposed a 'redefinition' of folklore which was necessary because of the initial and subsequent inconsistencies that he perceived in its conceptualization. Herskovits pointed out that the "lore" in William Thoms' newly coined compound was synonymous

4. The first nine annual meetings (I889-I897) of the American Folklore Society were held
independently. The next four meetings (I898-I9OI) were held together with the American
Society of Naturalists. The I5 $5^{\text {th }}$ meeting (I9O3) was independent again, but from I9I6 to I94I
the annual meetings were held together with the American Anthropological Association.
No meetings were held $1942-1943$ and after four more independent meetings (I944[2]-
I946] the American Folklore Society alternated its annual meetings between the American
Anthropological Society and the Modern Language Association until I966, when it began
and continued to meet independently (see Susan A. Dwyer-Shick, I979). At the time, such
a schedule represented the history of academic folklore in the United States, see Rosemary
Lévy Zumwalt (I988). 5. Signed with the pseudonym Ambrose Merton, the "Folklore" appeared first in a letter to the editors of The Athenaeum written on I2 August, I846. See The Athenaeum no. 982 (22 August, 1846): 862-863. For studies about William Thoms and the coinage of the term "folklore", see Duncan Emrich (I946); Richard M. Dorson (I955; I968: 75-90); Marian A. Smith (I947).

6. See J. Gersehnhorn (2004) and L. M. Smith (2009). 
with 'literature,' yet he proposed the new term as a substitution for 'popular culture' not literature, nor popular literature. For him 'popular antiquities' consisted of "manners customs, observances, and superstitions," but he also included "ballads and proverbs, etc." in the mix. Thirty-two years later, Herskovits noticed that in a recapitulation of the original coinage Thoms repeated the same inconsistency in the first "Rule" of the newly founded Folk-Lore Society, of which he was the director: "The Folk-Lore Society has for its object the preservation and publication of Popular Traditions, Legendary Ballads, Local Proverbial Sayings, Superstitions and Old Customs (British and foreign), and all subjects relating to them" (Herskovits 1946: 90). As the term became ubiquitous, and gained world-wide acceptance, folklore became the object of explanatory theories that amplified its inherent discrepancies. Evolutionary theories rationalized folklore as vestiges of human primitiveness, and national sentiments upheld it as the bond that binds a nation. The quaintness of the "folk" collided with the expansion of the concept to embrace societies, regardless of their economic position. The American scene further complicated matters by having to cope with migrant and native traditions. As a solution to these multiplying dilemmas, Herskovits opted to consider folklore as 'folkliterature' only (Herskovits I946: IOO).

Raglan took a distinctly different approach. He evaluated the state of folklore as a subject of intellectual inquiry negatively for three reasons. The first is that to confine one's studies to moribund superstitions is a somewhat gloomy and barren proceeding, little calculated to attract those who are interested in both the present and the past. Secondly, the class of matter which has filled our journal for so many years is obviously tending towards exhaustion. Thirdly, many of the customs and beliefs which were new to the earlier students of folklore are now known to be, or to have been, universal in Britain, if not throughout the world (Raglan i946: 98).

His solution itself was inconsistent with his observation. Instead of abandoning the subject and its name, as some American folklorists proposed fifty years later, ${ }^{7}$ he proposed, as a few students of folklore had done before him, to reconfigure folklore as a science, ${ }^{8}$ a historical science to be exact, but its subject matter would not reflect the global or even national, political, social or economic changes, but rather the regional historical changes in everyday life. ${ }^{9}$

7. See Jane C. Beck (1997); Regina Bendix (I998); Barbara Kirshenblatt-Gimblett (1998). For objections to the name change see Ben-Amos (1998) and Elliott Oring (I998).

8. Wilhelm Heinrich Riehl (I859); Johann Georg, von Hahn (I864); George W. Cox (I88I); Edwin Sidney Hartland (I89I); George Laurence Gomme (1908); Alexander H. Krappe (1930). The scientific and academic status of folklore has been a perennial issue in folklore scholarship; see for example, Munro S. Edmonson (I97I); W. Brückner and K. Beitl (eds.) (I983).

9. By the time Lord Raglan made his proposal the history of everyday life was already an established research trend in historical studies across the English Channel in France, where in I929 Marc Léopold Benjamin Bloch (I886-I944) and Lucien Paul Victor Febvre (I878-I956) had launched the Annales d'Histoire Economique et Sociale, thereby initiating an influential school in historical research that incorporated everyday life into the academic scrutiny of history. For a selection of studies of historiographical research about the "Annales" school, see N. Birnbaum (I978); M. Bloch and L. Febvre (1994-2003); A. Burguière (2006); P. Burke (I990); S. Clark (ed.) (I999); C. Fink (I989); R. Forster (I978); M. Harsgor (I978); L. Hunt (I986); J. Tendler (20I3). 
The reconceptualization of folklore was not limited to anniversaries. Six years later, Archer Taylor, then president of the American Modern Language Association, considered folklore as a representation of "associative thinking". For him, folklore deals with materials which have been shaped and handed on by associative rather than logical thinking. A ballad or a superstition is a bit of folklore in which associative thinking has been chiefly operative in its preservation. Its form, its use, and the characteristic variations of its several versions are determined by unconscious, not conscious, processes (Taylor I952). ${ }^{\mathrm{O}}$

In his characterization of folklore, Archer Taylor invoked the concept of association of ideas that Edward B. Tylor (1832-I9I7) perceived to be at the basis of "occult science (Tylor I958: II5-II6). Or, he could have had in mind the principle of 'pre-logical thinking' that Lucien Lévy-Bruhl (I857-I939) proposed as the distinctive feature of primitive societies (Lévy-Bruhl I9I9), and to whose writings he specifically referred in a previous essay (Taylor I946: IO4). ${ }^{\text {II }}$ In any case, such a concept only added coal to the fire of confusion that smoldered among folklorists at the time.

Mid-century was an ambivalent milestone for folklore. On the one hand, leading scholars could look back with pride at the major strides the discipline had taken and the tangible scholarly accomplishments of the twentieth century. ${ }^{12}$ But on the other hand, the attempts to frame these very achievements conceptually as the subjects of a single scholarly discipline entangled themselves by the multiple strands and lines of thought and interdisciplinary theories and methods that were brought to bear upon the themes, objects, and forms of folklore. The twenty-one short definitions that Maria Leach assembled in her valuable Funk \& Wagnalls Standard Dictionary of Folklore Mythology and Legends ${ }^{13}$ exposed the pitfalls scattered on the road that led to an answer to the question of "what is folklore?". In a retrospective essay, Francis Lee Utley identified 'orality' and 'tradition' as the two features that recurred most often in those definitions of folklore and which could therefore be considered its common denominators (Utley I96I). However, his proposal disregarded the many non-common denominators that plagued the discipline and prevented folklorists from articulating a comprehensive analytical conception.

The list of scholars who defined folklore in Leach's Dictionary reads like an examination question in a course on the history of folklore. True, some prominent names are missing. For example, Roman Jakobson (I896-I982), who contributed an excellent essay to the Dictionary on Slavic mythology, ${ }^{\mathrm{I}}$ and who had by then published his influential, yet at the time little known, article that he wrote together with Peter Bogatyrëv (I893-I97I) on the uniqueness of folklore, ${ }^{15}$ and

IO. See also his earlier essay: Taylor (I946).

II. He did not mention this concept in the definition of folklore that he proposed around the same time in the Funk and Wagnalls Dictionary. See note I3 below.

I2. Stith Thompson (ed.) (I953).

I3. Reprinted in Journal of Folklore Research no. 33 (I996): 255-264.

I4. Jakobson (I949-I950). The essay he wrote together with Petr Bogatyrëv is directly pertinent to the issue of the definition of folklore, so his absence from the list is an enigma. I5. Bogatyrëv and Jakobson (I929). See also: Heda Jason (I99I). 
Ralph Steel Boggs (I9OI-I994), ${ }^{\text {I6 }}$ the internationally known scholar of Hispanic folklore, were not included. Yet the list represented the breadth and depth of folklore scholarship in the United States in the I940s, and the differences among the scholars stretched the idea of interdisciplinary studies to its bewildering limits.

A flurry of definition articles followed, attempting to put our house in order. Senior scholars sought to establish the disciplinary boundaries, particularly between anthropology and literature, or to merge them into a folkloristic perspective. ${ }^{17}$ In doing so they followed the American scholarly tradition in folklore that Rosemary Zumwalt described as "a dialog of dissent" (Zumwalt I988), while younger scholars sought to resolve the contradictions in previous theories, and forge ahead with their own answers to the puzzle of folklore. ${ }^{8}$

Scholarly history and the public space compounded the definitional frustration of folklore. In I950, my teacher Richard M. Dorson published his article "Folklore and Fake Lore" in which he lambasted the commercial and popular use of folklore. At the core his criticism is the distinction between folklore in society, and its display in popular culture for either commercial, nationalistic, or exhibitionary purposes. In the same period, side by side with the rise of folklore in popular publications, the increased visibility of the folksong revival movement challenged the concept of folklore as a research subject. ${ }^{19}$ Should the theatricality of folklore be considered to be on the same level as the performance of folklore in its indigenous society, either urban or rural, literate or non-literate? Was it not this very phase of folklore that generated the question of authenticity? ${ }^{20}$

These issues contributed to the frustrations of my friends in folklore and my own. Slowly, the definition of folklore became a personal need rather than a task. It became necessary for me to distance myself from the sources of our confusion, and ask myself, as simply as I could, three interrelated questions: Is folklore real? That is to say, is "folklore" a figment of our ideational or ideological history, or is it a social and cultural reality? And, by any other name, does it still exist and is it cognitively distinct? If so, is it universal or socially and historically ephemeral, a passing phenomenon that disappears from the socio-cultural scape as societies change? Thirdly, how do people, behaviorally, linguistically and cognitively, distinguish their folklore acts within their own social life? If the reality and universality of folklore are theoretical premises, its behavioral aspect is observable and subject to description, analysis, and interpretation which are the tasks of the discipline of folklore. In my limited previous studies and research I encountered

I6. He was a folklorist of international reputation who taught in the Department of Romance Languages at the University of North Carolina where he founded the Curriculum in Folklore in 1939. For a bibliography of his publications up to mid-century, see Boggs (195I).

I7. For example (listed in order of their publications): William R. Bascom (I953; I955); Marian W. Smith (1959); Francis Lee Utley (1958; I96I).

I8. See, for example, Roger D. Abrahams (I963); Elli-Kaija Kongas (I963); Alan Dundes (I965; I966).

I9. See Ronald D. Cohen (2002); Ian Russell and David Atkinson (eds.) (2004).

20. See Regina Benedix (I997); Leslie Pincus (I996); Theodor W. Adorono (I973); Jacob Golomb (I995). 
folklore only as it was mediated in literature and available in print, ${ }^{2 \mathrm{I}}$ but in order to define it as a pragmatic social reality, I needed to encounter it in social life.

For that purpose I drew upon my still fresh experience of living among the Edo people in Nigeria in I966 and researching their oral tradition. Listening to them telling their stories, singing their songs, citing their proverbs, playing their music, and watching them dancing, decorating their shrines, worshiping their gods, and performing their rituals brought me into direct contact with the reality of folklore. But at that point it was necessary for me to translate this experience into conceptual terms of a definition that would not only describe but also frame folklore as a subject of analytical research. Such a reflexive transformation of experience required the phenomenon explored not only by folklore as a discipline but also by science in general to be identified. Obviously, the amount of scholarship on the philosophy of science is considerable and I would not be able to pursue all the possible answers to this fundamental problem. The portal through which I entered into this area of knowledge was Alfred North Whitehead's essay "Process and Reality", first published in 1929 and presented at the University of Edinburgh in 1927 and $1928 .{ }^{22}$ My definition is not an application of Whitehead's philosophy to folklore, yet his essay, or what I understood of it, helped me re-orient myself from what was considered an itemoriented exploration of reality, part of the intellectual heritage of antiquarianism and curiosity collecting that was inherent in the formative stages of folklore, ${ }^{23}$ to a process orientation. Folklore, I reasoned, had a reality of its own before it was put into file cabinets, before it was classified into motifs and types, and before it was the subject of romantic idealization. ${ }^{24}$ What was that reality?

Other disciplines had to record and examine facts as well, but the recording was part of the observation rather than the events themselves. And at that stage Whitehead was helpful. He proposed that we observe and study processes in nature and in society. We study reality in flow as interactions, relations and movement. Disciplines examine processes rather than static conditions. Students may freeze them for observations and scrutiny purposes, or may abstract them into ideal types as Max Weber proposed, ${ }^{25}$ but these technical means of documentation are necessary only because of our own limited abilities of observation. All the archival research into which historians delve purports to uncover not isolated documents, but causal relations between events along a temporal axis that have an explanatory value and reveal processes in time. The concept of process is applicable to all other disciplines in the social sciences, the humanities and, of course, the natural sciences, yet, as far as folklore is concerned, it would be

2r. My MA thesis was entitled "In Praise of the Besht: Commentary and Motif-Index" (I964), later incorporated into the translation that Jerome Mintz and I published In Praise of the Baal Shem Tov (1970), and my doctoral dissertation was on "Narrative Forms in the Haggadah: Structural analysis" (I967C).

22. F. S. C. Northrop and Mason W. Gross (eds.) (I96I): 567-746.

23. Dorson (I968: I-90).

24. Abrahams (1993).

25. For a selection of studies about the concept of "ideal type" in Max Weber's sociological theory see Becker (I933-I934; I940); Burger (I976); Cahnman (I964; I965); Rogers (I969); Weber (I947; I949); for the application of this concept to folklore see Ben-Amos (I992); Honko (I968; 1976; 1980; 1989a; 1989b). 
necessary to identify the particular process that universally exists in human societies which folklore, as a discipline, explores.

There is an inherent incongruity between processes in society and academic disciplines. Society and nature do not come packaged ready made for university departments to study and, if anything, the relation between the organization of the academy and the order of society and nature is inverted. Disciplines attempt to adapt to study reality, but even then the correspondence between the two is far from perfect. By the mid I96os folklore as a concept and as a discipline had a history that was long enough to extend in different directions, which complicated the demarcation of folklore in the social context. At the time, my own department at the University of Pennsylvania was named "Folklore and Folklife" partially reflecting the twists and turns of its academic history rather than social changes in the United States (Miller 2004). I therefore first attempted to identify the process in society that could best be described as 'folklore' before going on to deal with its academic representation.

For this purpose, following my experience in my field study, I isolated "communication" as the process of folklore. It could be verbal, visual, musical or kinetic but it had to involve the process of communication. It was not the first time that the concept had occurred in folklore scholarship, ${ }^{26}$ but my direct inspiration was the special issue of the American Anthropologist edited by John Gumperz and Dell Hymes, which they titled "The Ethnography of Communication" (I964), and, in particular, Hymes' introductory essay "Introduction: Toward Ethnographies of Communication" (Hymes 1964). Hymes envisioned the ethnography of communication as a "second descriptive science comprising language" which centers holistically on communicative events and of which language is just one of the components. ${ }^{27}$

Such an idea of communication could provide a solid foundation for the study of folklore but, as proposed, it was both too broad and too narrow, since it excluded such non-linguistic forms of communication as visual arts, music and dance, that were part of the paradigm of the discipline of folklore. Indeed, the history of the discipline was not a major concern for me at the time. I deliberately considered the concept of "tradition", ${ }^{28}$ which was an integral feature of folklore,

\section{For example, R. Bascom (1955: 247).}

27. The essay became one of the series of Hymes' influential contributions. Dell Hymes (I927-2009) continued to produce illustrious scholarship. He was the president of three scholarly organizations: the American Folklore Society (I973-I974), the Linguistic Society of America (1982), and the American Anthropological Association (1983). Some of his major studies in folklore were collected in his books Foundations in Sociolinguistics: An Ethnographic Approach (1974) and "In Vain I Tried to Tell You:" Essays in Native American Ethnopoetics (I98I).

28. The deletion of the concept of "tradition" from the definition of folklore became one of its most controversial aspects. In folklore studies and in related fields, "tradition" was and continued to be, a major idea that was explored and analyzed in scholarship and in society, regardless of its elimination by me from the defining criteria of folklore. For a selection of studies about tradition see: Anttonen (2005); Becker (1998); Blank and Howard (2013); Bronner (I998, 20II); Cashman et alii (20II); Gaily (I989); Glassie (I995); Hobsbawm and Ranger (I983); Honko (I988); McDonald (I997); Shils (I98I); Utley (I96I); Watson (I997). Tongue in cheek, when Linda Dégh guest edited an issue of the Journal of Folklore Research on "Culture, Tradition, Identity" she invited me to write an essay about "tradition", see Ben-Amos (I984). 
to be an optional, not a defining, criterion. ${ }^{29}$ But not only past scholarship was at stake. There was a need to establish a correspondence between the socio-cultural and the scholarly-analytical conceptions of folklore. For that purpose, I proposed that folklore was a unique kind of communication that is distinct in words, in sight, in sound, in motion and in performance.

"Artistic" was not an evaluative but a descriptive term, indicating the aesthetic dimension of its performance. It is artistic by the very nature of its distinction from the quotidian forms of communication that we encounter in society. Using verbal folklore as an example, speakers discern the forms of speaking folklore by employing such verbal markers as opening and closing formulas, style and register, narrative patterns, thematic domains. These markers distinguish them from other forms of verbal communication, and subject them to culturally cognizant performance rules. Folklore scholarship engages in the analysis and interpretation of these verbal genres that are conceived as artistic by the community of speakers.

At that time, I had not read the article by Peter Bogatyrëv and Roman Jakobson, "Die Folklore als eine besondere Form des Schaffens", which was published in I929 (Bogatyrëv-Jakobson I929). However, by selecting the concept of "art" as the modifier of communication I was probably influenced by the writings of the school of Russian formalism - to which I had been exposed through the writings of Vladimir Propp (I895-I970) that had begun to be available in English - and some students at the Folklore Institute of Indiana University to whom I referred in my dissertation. ${ }^{30}$

But the modification of "communication" as artistic, though necessary, was not sufficient. Forty-six years ago, before the exponential leap in communication technology that we are currently experiencing, it was possible to broadcast or telecast a song for millions of listeners, and refer to it as a "folk-song". Was such communication still a folkloric event? My conclusion was that it transcended its folkloric boundaries. Society at large considered such performances as "masscommunication". Maybe it was folklore being displayed in another medium, but it was not a folkloric performance. Therefore, in addition to aesthetic modification there was a need to add the social modification of folklore. Therefore, I proposed that folklore was "artistic communication in small groups", involving face-toface communication in an event in which performers and their audiences share the same symbolic universe.

I first delivered my paper "Folklore: The Definition Game Once Again" in the 1967 Annual Meeting of the American Folklore Society in Toronto, Canada. I was scheduled to talk in a panel on "Oral and Written Literatures", chaired by Professor D.K. Wilgus (University of California, Los Angeles), in which the other speakers were Alan Lomax (New York, N.Y.), Robert J. Adams (Indiana University)

29. Ben-Amos (I97I: I3-I5).

30. Today Vladimir Yakovlevich Propp is recognized as a major folktale and literary scholar. The first translation of his ground-breaking morphological analysis of the folktale was published at Indiana University in 1958 and had an immediate influence on the students at the Folklore Institute. A second edition appeared ten years later as part of the American Folklore Society Bibliographical and Special Series. For bibliographical details of books in English by and about him and his method, see the References: V. Propp (1968; 1984; 2012) and A. Dundes (I964b), P. Gilet (I998), Milne (I988) and see I. Levin (I967). 
a specialist on Japanese folklore and a class mate of mine, and Barre J. Toelken (University of Oregon), whom I barely knew at the time but who later became a good friend, a scholar of ballads and Navajo folklore. I was the last. Alan Lomax (I9I5-2002) was the most senior scholar in the group and, appropriately enough, dominated the panel. ${ }^{3 \mathrm{I}}$ He spoke freely beyond his allotted 20 minutes, and put the rest of us under time pressure. By the time I had my turn, lunch time was approaching. I started setting up my argument, developing the ideas and leading up to the definition of folklore which I was about to propose, but the chairman, D. K. Wilgus, asked me impatiently to hurry up and finish my presentation. As I learned later, it was not just his hunger that prompted him to cut me short.

Upon my return from Toronto, I took some time to prepare my paper for publication and, on the advice of colleagues, changed its title to a more respectable, and to my taste somewhat pretentious, "Toward New Perspectives in Folklore" and mailed it to the Journal of American Folklore. The editor, Professor John Greenway (I9I9-I99I) rejected my manuscript. However, he made a concession, and told me that he had forwarded it to Professor Américo Paredes (I9I5-I999) of the University of Texas, who by that time, was the editor-elect of the Journal of American Folklore. Américo Paredes later told me personally that while he did not know whether my manuscript was the last that John Greenway rejected, he remembered quite well that it was the first he approved for publication in the Journal of American Folklore.

Instead of my paper, John Greenway published in the Journal "A Note on Definitions" by Roger Welsch (I968) who was my class-mate at Indiana University. By that time he was teaching at the German Department of the University of Nebraska. He was an excellent young scholar and in 1967-I968 was probably working on the translation of Kaarle Krohn's (I863-I933) Methodology of Folklore, introducing American students to a folklore classic (Krohn I97I). He subsequently became a distinguished folklorist of the Prairie Plains, publishing eleven books and counting. ${ }^{32}$ Welsch pointed out the futility of definitions in general and criticized my own definition in particular. He admonished folklorists for their recurrent attempts to define folklore, pointing out that it is in the nature of words to constantly change meanings and the term "folklore' was not unique in that regard. Definitions, he argued, are linguistic not folkloric problems. His note was eloquent and sophisticated, making me realize the apparent vagueness of my own lecture. My argument did not concern the word "folklore" but with the social and verbal conduct that societies designate as distinct from other forms of behavior, and to which scholars applied the term folklore.

The person who came to my defense was Richard Bauman, a friend and a class mate who, after obtaining an MA degree in folklore from Indiana University, continued his studies at the University of Pennsylvania, specializing in American Civilization and Anthropology. He was later to become the editor of the Journal of American Folklore himself, and an internationally known scholar who authored many books on performance theory in folklore. ${ }^{33}$ He wrote:

3I. For a selection of his writings see Cohen (2003), and for his biography Szwed (2010).

32. He published eleven books the latest of which is Embracing Fry Bread (2012).

33. A selection of his studies are: R. Bauman (I983; I986; I975; 2004). He edited the Journal of American Folklore (I98I-I985). 
If ever a writer has hobbled a truly significant contribution with an infelicitous title, it is Dan Ben-Amos, with his "Folklore: The Definition Game Once Again," delivered at the Toronto meetings of the American Folklore Society in I967. For it is abundantly obvious that folklorists have grown weary of the old game, and Roger Welsch has undoubtedly struck a responsive chord in many of his colleagues by coming forward to say so even before Ben-Amos's paper has appeared in print. The truth of the matter is, however, that Ben-Amos is not really playing games, or at least he has so rewritten the rules that the game is a brand new one, and agree or disagree with his ideas, we do ourselves little disservice to dismiss them as another tired whack at the same tattered ball. His paper will speak for itself when it appears in print, but certain points raised by Welsch need to be answered now, if only to make it possible for Ben-Amos's contribution to receive the full attention it deserves. Fortunately, this has nothing to do with the essential points of Ben-Amos's work. Insofar as the kind of exercise described above represents the definition game, Ben-Amos has explicitly dissociated himself from it. Instead - and would that he had stressed this in his subtitle - Ben-Amos has entered into a major reconceptualization of the entire field of folklore. His work must be considered in that light. For it is plain that Ben-Amos is not talking about the materials of folklore - the folklore things of the world - and he certainly does not intend to include himself among the legions of item-oriented folklorists. The significance of his contribution, rather, lies in his suggestion that folk-lore be considered in terms of communicative process, communicative action; he is doing no more and no less than advancing the concept of a behavioral study of folklore, thereby opening the way for a behavioral science of folklore. Now - while Welsch and other humanists recoil in horror and indignation - let us consider some of the implications of this reorientation for those who, like myself, find the prospect of such a science highly promising and not uncongenial. The idea of folklore as a social science is a relatively familiar one by now, recognized, if not put into practice, by most folklorists. Even the literarians seem generally inclined to grant it some legitimacy, if only on a live-and-let-live basis. But folklore as a behavioral science is something new (Bauman I969: I67). ${ }^{34}$

Later Richard Bauman was instrumental in according attention to my definition of folklore. He came to the University of Texas in I967, as post-doctoral scholar, and when Professor Américo Paredes assumed the editorship of the Journal of American Folklore, in I968, starting with vol. 82 (I969), Richard Bauman became his colleague. Together they began to plan an issue devoted to folklore theory, for which Richard Bauman became a "special editor". 35

In the summer of I970 I was teaching summer courses at Indiana University, and was asked by my then former teacher, Professor Richard Dorson, to read and comment on my manuscript. He had previously been the editor of the Journal of American Folklore (I959-I963) and a teacher whose judgment I trusted. After

34. Richard Bauman's comment appeared in the Journal of American Folklore, after Américo Paredes assumed its editorship.

35. The issue "Toward New Perspectives in Folklore" appeared in the Journal of American Folklore 84, no. 33I (I97I): iii-ix, 3-I7I, and was later published as a special publication of the American Folklore Society. 
reading the manuscript, he said: "The paper is fine, but you have to state in the title what is unique about your definition. How does your definition differ from all other definitions of folklore?"

"Well", I answered, "I am defining folklore in context."

"So, say so",

I immediately wrote to Américo Paredes asking him to change the title of my essay from "Toward New Perspectives in Folklore" to "Toward a Definition of Folklore in Context". And by the time he and Richard Bauman were ready to publish the theoretical issue of the Journal of American Folklore he asked me for permission to use the discarded title of my paper as the title of the issue.

The concept of context that I spontaneously selected to highlight in the title, preferring it over any of the terms within the definition, was not new in folklore scholarship. In his Guide for Field Workers in Folklore, Kenneth Goldstein distinguished between artificial, formal, informal, natural, physical, semi-formal, and social contexts (Goldstein I964: I90). Alan Dundes and Roger Abrahms considered the methodological significance of "context" in the analysis of folklore texts, and in a retrospective essay that I wrote twenty years after the publication of "Toward A Definition of Folklore in Context" I discussed previous uses of the concept in folklore studies and related disciplines. ${ }^{36}$ But in their use and in their theoretical discourse of folklore, "context" is a concept relating to interpretive information regarding the meanings of texts. I assumed that much, taking the integral relations of texts and their contexts for granted. By inserting the preposition "in" into the title of my essay, I intended to indicate that the definition I proposed is tenable to folklore as it exists, occurs and is performed in context, considering all the attributes that have often figured in the definitions of folklore, secondary, optional and, in fact, unnecessary features for definitional purposes (Ben-Amos I983). Folklore is, therefore, "artistic communication in small groups" as it happens pragmatically in culture and society.

When it finally appeared in print the essay and the definition received a mixed reaction. The most visible, or rather vocal, was D. K. Wilgus' "Presidential Address" delivered at the I972 Annual Meeting of the American Folklore Society in Austin, Texas (Wilgus I973). Quoting the venerable scholar George Layman Kittredge (I860-I94I), Wilgus' address was a frontal attack on the theory, the method, and the terminology of these up-starts in folklore who collected their works between the two covers of the "New Perspectives". Richard Bauman's and my own essays were well represented as targets of criticism. While listening to his speech, both of us glanced at each other, with admitted satisfaction. We realized that if we, mere youngsters in the field of folklore, had become the ire of the president of the American Folklore Society we had done something right.

Other leading scholars at the time had a more ambivalent response. Richard Dorson, for example, who himself began his scholarship in folklore by ruffling some feathers with his neologism "fake-lore", empathized with his former students, considering them "young Turks among folklorists" (Dorson I972: 45). ${ }^{37}$ At the same time, in commenting about the New Perspectives in his own book

36. See Alan Dundes (1964a); Roger D. Abrahams (I968); Dan Ben-Amos (I993).

37. His introductory essay to this edited volume is mostly a reprint of his article "Current Folklore Theories" (I963), to which he added a discussion of the "Contextualists" (I972: 45-47). 
Folklore and Fakelore he expressed his own reservations, concluding that there was nothing new in this new trend (Dorson I976: 86-87), epitomizing William James' observation that a new theory is first rejected, next admitted as true but insignificant and finally considered not new at all (James I907: I98).

The folklorists who were younger forty-six years ago were more receptive..$^{8}$ In my own work I made some digressions into more traditional folklore methodologies, but even while pursuing them, this definition of folklore and the concept of folklore that is at its core sustained me and continued to be the fundamental premise of my studies.

\section{References}

ABRAHAMS, Roger D. (I963): "Folklore in Culture: Notes toward an Analytic Method". Texas Studies in Literature and Language no. 5 (Spring I963): 98-IIo.

- (I968): "Introductory Remarks to a Rhetorical Theory of Folklore". Journal of American Folklore no. 8I: I43-I58.

- (1993): "Phantoms of Romantic Nationalism in Folkloristics". Journal of American Folklore: 3-37.

Ademoyega, Adewale (198I): Why We Struck: The Story of the First Nigerian Coup. Ibadan, Nigeria: Evans Brothers.

Adorono, Theodor W. (I973): The Jargon of Authenticity. Trans. Knut TARnOwSKI and Frederic WILL. Evanston: Northwestern University Press.

Agwuncha Nwankwo, Arthur (1987): Power and Violence in Nigerian Politics. Enugu, Nigeira: Fourth Dimension Publishing Co.

AKINNOLA, Richard (I998): History of Coup d'etats in Nigeria. Lagos: Media Research and Resource Bureau.

Anttonen, Pertti J. (2005): Tradition through Modernity: Postmodernism and NationState in Folklore Scholarship. Helsinki: Finnish Literature Society.

BASCOM, William R. (I953): "Folklore and Anthropology". The Journal of American Folklore no. 66: 283-290.

- (I955): "Verbal Art". The Journal of American Folklore no. 68: 245-252.

BAUMAN, Richard (I969): “Towards a Behavioral Theory of Folklore: A Reply to Roger Welsch". Journal of American Folklore no. 82: I67-I70.

— (I975): "Verbal Art as Performance". American Anthropologist, New Series, vol. 77, no. 2 (June I975): 290-3II.

- (1983) Let Your Words be Few: Symbolism of Speaking and Silence among Seventeenthcentury Quakers. New York: Cambridge University Press.

- (I986): Story, Performance, and Event: Contextual Studies of Oral Narrative. New York: Cambridge University Press.

- (2004): A World of Others' Words: Cross-Cultural Perspectives on Intertextuality. Malden: Blackwell Publishing.

BAYARD, Samuel P. (I953): "The Materials of Folklore". The Journal of American Folklore no. 66: I7.

BECK, Jane C. (1997): “Taking Stock: I996 American Folklore Society Presidential Address". Journal of American Folklore no. IIO: I23-I39.

BECKER, Howard (I933-I934): “Culture Case Study and Ideal-Typical Method: With Special Reference to Max Weber”. Social Forces no. I2: 399-405.

38. For example, see H. Glassie (I983: I29). 
- (1940): "Constructive Typology in the Social Sciences". In Contemporary Social Theory. Eds. Henry E. BARNES, Howard BECKER and Frances BECKER. New York: Appleton-Century, p. I7-47.

BECKER, Jane S. (I998): Selling Tradition: Appalachia and the Construction of an American Folk, I930-I940. Chapel Hill: The University of North Carolina.

BeN-Amos, Dan (I963a): "Folklore in Israel”. Schweizerisches Archiv für Volkskunde no. 59: I4-24.

- (I963b): "Hebrew Parallels to Indian Folktales". Journal of the Assam Research Society no. I5: 37-45.

- (I963c): "The Situation Structure of the Non-Humorous English Ballad". Midwest Folklore no. I3: I63-I76.

- (I964): "In Praise of the Besht: Commentary and Motif-Index". Unpublished M. A. Thesis. Bloomington: Indiana University.

— (I967a): "Ikpomwosa Osemwegie: A Young Bini Poet". Nigeria Magazine no. 94: 250252.

— (I967b): "Story Telling in Benin". African Arts/Arts d'Afrique no. I: 54-59.

- (I967c): "Narrative Forms in the Haggadah: Structural Analysis". Unpublished Dissertation. Bloomington: Indiana University.

- (ed.) (1970): In Praise of the Baal Shem Tov. Editor and translator, in collaboration with Jerome R. Mintz. Bloomington: Indiana University Press.

- (I97I): "Toward a Definition of Folklore in Context". Journal of American Folklore no. 84:3-I5.

- (I983): "The Idea of Folklore: An Essay". In Studies in Aggadah and Jewish Folklore edited by Issachar BEN-AMI and Joseph DAN. Folklore Research Center Studies 8. Jerusalem: The Magnes Press, p. II-I7. [Reprinted in Victor D. SANUA (ed.): Fields of Offerings: Studies in Honor of Raphael Patai. Cranberry, N.J.: Associated University Presses, I983, p. 47-64; Alan Dundes (ed.): Folklore: Critical Concepts in Literary and Cultural Studies. Vol. I. London: Routledge, 2005]

- (I984): "The Seven Strands of Tradition: Varieties in Its Meaning in American Folklore". Journal of Folklore Research no. 21: 97-I3I.

— (I992): Do We Need Ideal Types (in Folklore)? - An Address to Lauri Honko. NIF Papers no. 2. Turku: Nordic Institute of Folklore.

— (I993): "Context in Context." Western Folklore no. 52 : 209-226.

- (I998): "The Name Is the Thing". Journal of American Folklore no. III: 257-280.

BENDIX, Regina (I997): In Search of Authenticity: The Formation of Folklore Studies: Madison: University of Wisconsin Press.

- (I998): "Of Names, Professional Identities, and Disciplinary Futures." Journal of American Folklore no. III: 235-246.

BIRnBAUM, Norman (I978): “The Annales School and Social Theory [with Discussion]”. Review (Fernand Braudel Center) no. I: 225-242.

Blank, Trevor J. and Robert Glenn Howard (eds.) (20I3): Tradition in the Twenty-First Century: Locating the Role of the Past in the Present. Logan: Utah State University Press.

Bloch, Marc; Lucien Febvre (1994-2003): Marc Bloch, Lucien Febvre et les Annales d'histoire économique et sociale: correspondance. 3 vols. Ed. Bertand Müller, Paris: Fayard.

BOGATYRËV, Peter; Roman JAKOBSON (I929): "Die Folklore als eine besondere Form des Schaffens". In Donum natalicum Schrijnen, verzameling van opstellen opgedragen aan... Jos. Schrijnen bij gelegenheid van zijn zestigsten verjaardag, 3 Mei I929. Utrecht: Dekkera and Van der Vegt, p. 900-9I3. [Revised version: Roman JAKOBSON: Selected Writings. The Hague: Mouton, I966, 4, p. I-I5; English translation: Peter STEINER 
(ed.): The Prague School: Selected Writings, I9I9-I946. Austin: University of Texas Press, I982, p. 32-46.]

Boggs, Ralph Steele (I95I): "Bibliography of R. S. Boggs Through I950". Folklore Americas no. II 2 (I95I): I-I3.

Bronner, Simon J. (1998): Following Tradition: Folklore in the Discourse of American Culture. Logan, Utah: Utah State University Press.

- (20II): Explaining Traditions: Folk Behavior in Modern Culture. Lexington, KY.: The University Press of Kentucky.

BRÜCKNER, Wolfgang; Klaus BEITL (eds.) (I983): Volkskunde als akademische Diszipline. Studien zur Institutionelausbildung. Referat eines wissenschaftsgeschichtlichen Symposions vom 8.-Io. Oktober I982 in Würzburg. Österreichische Akademie der Wissenschaften, Philosophisch-Historische Klasse 4I4. Vienna: Der Österreichische Akademie der Wissenschaften.

BRunvand, Jan Harold (1968): The Study of American Folklore: An Introduction. New York: W. W. Norton and Co.

BURGER, Thomas (1976): Max Weber's Theory of Concept Formation: History, Laws, and Ideal Types. Durham, NC: Duke University Press.

BurguiÈre, André (2006): The Annales School: An Intellectual History. Trans. Jane Marie Todd. Ithaca: Cornell University Press.

BURKe, Peter (1990): French Historical Revolution: the Annales School, 1929-89. Standford, California: Stanford University Press.

CaHnman, Werner J. (I964): "Max Weber and the Methodologica Controversy in the Social Sciences". In Sociology and History: Theory and Research. Eds. Werner J. CAHnMan and Alvin Boskoff. New York: The Free Press, p. IO3-I27.

- (I965): "Ideal Type Theory: Max Weber's Concept and Some of Its Derivations." Sociological Quarterly no. 6: 268-280.

Cashman, Ray, Tom Mould and Pravina Shukla (eds.) (20II): The Individual and Tradition: Folkloristic Perspectives. Special Publications of the Folklore Institute, no. 8. Indiana University Bloomington. Bloomington: Indiana University Press.

Clark, Stuart (ed.) (I999): The Annales School: Critical Assessments. 4 vols. London: Routledge.

Cohen, Ronald D. (2002): Rainbow Quest: The Folk Music Revival and American Society 1940-1970. Amherst and Boston: University of Massachusetts Press.

- (ed.) (2003): Alan Lomax: Selected Writings I934-I997. New York: Routledge.

Cox, George W. (I88I): An Introduction to the Science of Comparative Mythology and Folklore. New York: H. Holt and Co.

Dorson, Richard M. (I955): “The First Group of British Folklorists”. The Journal of American Folklore no. 68: 333-340.

- (I963): "Current Folklore Theories". Current Anthropology no. 4: 93-II2.

- (I968): The British Folklorists: A History. Chicago: The University of Chicago Press.

- (1976): Folklore and Fakelore: Essays toward a Discipline of Folk Studies. Cambridge, Mass.: Harvard University Press.

- (ed.) (1972): Folklore and Folklife: An Introduction. Chicago: University of Chicago Press.

Dundes, Alan (I964a): “Texture, Text, and Context". Southern Folklore Quarterly no. 28: 25I-265. [reprinted in Alan DuNDES: Interpreting Folklore. Bloomington: Indiana University Press, I980, p. 20-32.]

- (I964b): The Morphology of North American Indian Folktales. Folklore Fellows' Communications I95. Helsinki: Suomalainen Tiedeakatemia.

— (I965): “What Is Folklore?". In Alan Dundes (ed.): The Study of Folklore. Englewood Cliff, N.J.: Prentice-Hall, p. I-3. 
- (I966): “The American Concept of Folklore". Journal of the Folklore Institute no. 3: 226-249.

DWYER-SHICK, Susan A. (I979): “The American Folklore Society and Folklore Research in America, I888-I940”. Unpublished Dissertation. Philadelphia: University of Pennsylvania.

EDMONSON, Munro S. (I97I): Lore: An Introduction to the Science of Folklore and Literature. New York: Holt Rinehart and Winston.

EMRICH, Duncan (I946): "Folklore: William John Thoms". California Folklore Quarterly no. 5 (I946): 355-374.

FInK, Carole (1989): Marc Bloch: A Life in History. Cambridge, UK: Cambridge University Press.

FORSTER, Robert (I978): "Achievements of the Annales School”. The Journal of Economic History no. 38: 58-76.

GAILY, Alan (I989): "The Nature of Tradition". Folklore no. IOo: I43-I6I.

Gershenhorn, Jerry (2004): Melville J. Herskovits and the Racial Politics of Knowledge. Lincoln: University of Nebraska Press.

GILET, Peter (1998): Vladimir Propp and the Universal Folktale: Recommissioning an Old Paradigm Story as Initiation. Middlebury Studies in Russian Language and Literature, vol. I7. New York: Peter Lang.

GLASSIE, Henry (I983): “The Moral Lore of Folklore”. Folklore Forum no. I6 (I983): I23I5I.

- (I995): "Tradition". Journal of American Folklore no. IO8: 395-4I2.

Goldstein, Kenneth S. (I964): A Guide for Field Workers in Folklore. Hatboro, Pennsylvania: Folklore Associates.

GolOMB, Jacob (I995): In Search of Authenticity: From Kierkergaard to Camus. London: Routledge.

GOMME, George Laurence (I908): Folklore as an Historical Science. London: Methuen.

GrojAhN, Martin (1966): Beyond Laughter: Humor and the Subconscious. New York: McGraw-Hill.

GuMPERZ, John J.; Dell Hymes (eds.) (I964): “The Ethnography of Communication”. Special Publication of American Anthropologist no. 66, 6, pt. 2.

HAHN, Johann Georg von (I864): Griechische und albanesische Märchen. 2 vols. Leipzig: W. Engelmann.

HARSGOR, Michael (I978): “Total History: The Annales School”. Journal of Contemporary History no. I3: I-I3.

Hartland, Edwin Sidney (I89i): The Science of Fairy Tales, An Inquiry into Fairy Mythology. London: W. Scott.

HASAN-Rokem, Galit (I998): "The Birth of Scholarship out of the Spirit of Oral Tradition: Folk Narrative Publications and National Identity in Modern Israel". Fabula no. 39: 277-290.

HersKovits, Melville J. (I946): "Folklore after a Hundred Years: A Problem in Redefinition". The Journal of American Folklore no. 59: 89-Ioo.

Hobsbawm, Eric and Terence RANGer (eds.) (I983): The Invention of Tradition. Cambridge, UK: Cambridge University Press.

НоNко, Lauri. (I968): "Genre Analysis in Folkloristics and Comparative Religion". Temenos no. 3: 48-66.

- (I976): "Genre Theory Revisited". Folk Narrative Research: Some Papers Presented at the VI Congress of the International Society for Folk Narrative Research. Studia Fennica no. 20: 20-26.

— (I980): "Genre Theory". Arv: Scandinavian Yearbook of Folklore no. 36: 42-45.

- (ed.) (I988): Tradition and Cultural Identity. Turku: Nordic Institute of Folklore. 
— (I989a): "Folkloristics Theories of Genre". Studies in Oral Narrative. Ed. Anna- Leena SIIKALA. Studia Fennica no. 33: I3-28.

— (I989b): "Methods in Folk Narrative Research". In Nordic Folklore: Recent Studies. Eds. Reimund Kvideland and Henning K. SEHMSDORF. Folklore Studies in Translation. Bloomington: Indiana University Press, p. 23-39.

HunT, Lynn (I986): "French History in the Last Twenty Years: The Rise and Fall of the Annales Paradigm". Journal of Contemporary History no. 2I : 209-224.

Hymes, Dell (1964): "Introduction: Toward Ethnographies of Communication". American Anthropologist vol. 66, no. 6, Special Publication "The Ethnography of Communication": I-34.

- (I974): Foundations in Sociolinguistics: An Ethnographic Approach. Philadelphia: University of Pennsylvania Press.

- (I98I): "In Vain I Tried to Tell You": Essays in Native American Ethnopoetics. Philadelphia: University of Pennsylvania Press.

JAKOBSON, Roman (I949-I950): "Slavic Mythology". In Maria LEACH (ed.): Funk \& Wagnalls Standard Dictionary of Folklore Mythology and Legends. 2 vols. Associate editor, Jerome FrIED. New York: Funk \& Wagnalls company, vol. 2, p. IO25-IO28.

James, William (1907): Pragmatism: A New Name for Some Old Ways of Thinking. New York: Longmans, Green and Co.

JASON, Heda (I99I): “Marginalia to P. Bogatyrev and R. Jakobson's Essay «Die Folklore als Eine Besondere Form des Schaffens»". Folklore no. IO2: 3I-38.

KirshenblatT-Gimblett, Barbara (I998): "Folklore's Crisis". Journal of American Folklore no. III: 28I-327.

KongAS, Elli-Kaija (1963): “The Concept of Folklore”. Midwest Folklore no. 13: 69-88.

KrAPPE, Alexander H. (I930): The Science of Folk-Lore. London: Methuen.

Krohn, Kaarle (I97I): Folklore Methodology. Formulated by Julius Krohn and expanded by Nordic Researchers. Trans. Roger L. WeLsCH. Publications of the American Folklore Society bibliographical and Special Series, vol. 2I. Austin, Texas: The University of Texas Press. [Originally published as Die folkloristische Arbeitsmethode. Oslo, Norway: The Institute for Comparative research in Human Culture, I926.]

KuHN, Thomas S. (I962): The Structure of Scientific Revolutions. International Encyclopedia of Unified Science, vols. I \& 2. vol. 2, no. 2. Chicago: The University of Chicago Press.

LEACH, Maria (ed.) (I949-I950): Funk \& Wagnalls Standard Dictionary of Folklore Mythology and Legends. 2 vols. Associate editor, Jerome Fried. New York: Funk \& Wagnalls Company. [Reprinted as "Definitions of Folklore". Journal of Folklore Research no. 33 (1996): 255-264.]

Levin, Isidor (1967): "Vladimir Propp: An Evaluation on His Seventieth Birthday." Journal of the Folklore Institute no. 4: 32-49.

LeVy-Bruhl, Lucien (I9IO): Les fonctions mentales dans les sociétés inférieurs. Paris: F. Alcan. [English Translation by L. A. Clare: How Natives Think. New York: A. A. Knopf, I925.]

LucкHAM, Robin (I97I): The Nigerian Military: A Sociological Analysis of Authority \& Revolt 1960-1967. Cambridge: Cambridge University Press.

MCDonald, Barry (I997): "Tradition as Personal Relationship". Journal of American Folklore no. IIO: 47-67.

Miller, Rosina S. (2004): "Of Politics, Disciplines, and Scholars: MacEdward Leach and the Founding of the Folklore Program at the University of Pennsylvania". The Folklore Historian no. 21: I7-34.

Milne, Pamela J (I988): Vladimir Propp and the Study of Structure in Hebrew Biblical Narrative. Sheffield: Almond Press. 
Northrop, F. S. C.; Mason W. Gross (eds.) (I96I): Alfred North Whitehead: An Anthology. New York: The Macmillan Company.

Noy, Dov (ed.) (I963): Folktales of Israel, with the assistance of Dan Ben-Amos. Chicago: Chicago University Press.

Nwachuku, Levi A.; G. N. Uzoigwe (2004): Troubled Journey: Nigeria Since the Civil War. Dallas: University Press of America.

Nwankwo, Arthur A. (1987): The Military Option to Democracy: Class, Power and Violence in Nigerian Politics. Enugu, Nigeira: Fourth Dimension Publishing Co.

Oyinbo, John (I97I): Nigeria: Crisis and Beyond. London: Charles Knight.

ORING, Elliott (I998): “Anti Anti-'Folklore”". Journal of American Folklore no. III: 328338.

Oriol, Carme (2OI2): “Josep M. Pujol (I947-2OI2)”. Fabula no. 53, 3-4: 295-298.

ORIOL, Carme; Josep M. PUjOL (2008): Index of Catalan Folktales. Folklore Fellows' Communications 294. Helsinki: Suomalainen Tiedeakatemia.

Oriol, Carme; Emili SAMPER (eds.) (2013): Això era i no era: Obra folklòrica de Josep M. Pujol. Tarragona: Publicacions Universitat Rovira i Virgili.

PANTER-Brick, S. K. (I970): "From Military Coup to Civil War January 1966 to May I967". In Nigerian Politics and Military Rule: Prelude to the Civil War. Commonwealth Papers I3. London: University of London and The Athlone Press, p. I4-57.

Paredes, Américo; Richard Bauman (eds.) (I972): Toward New Perspectives in Folklore. Publications of the American Folklore Society Bibliographical and Special Series, vol. 23. Austin, Texas: The University of Texas Press. [Second edition Bloomington, Indiana: Trickster Press, 200o.]

PINCUS, Leslie (I996): Authenticating Culture in Imperial Japan: Kuki Shuzo and the Rise of National Aesthetics. Berkeley: University of California Press.

Propp, Vladimir (I958): Morphology of the Folktale. Trans. Laurence SCOTT. Ed. Svatava PIRKOVA-JAKOBSON. International Journal of American Linguistics, 24, no. 4, part III. Publication Ten of the Indiana University Research Center in Anthropology, Folklore and Linguistics. Bloomington, Indiana: Indiana University.

- (I968): Morphology of the Folktale. $2^{\text {nd }}$ revised edition. Ed. Louis A. WAGNer. "Introduction" by Alan Dundes. Publications of the American Folklore Society Bibliographical and Special Series, vol. 9. Indiana University Research Center in Anthropology, Folklore and Linguistics, Publication Io. Austin: University of Texas Press.

- (I984): Theory and History of Folklore. Trans. Ariadna Y. MARTIN and Richard P. MARTin. Ed. Anatoly Liberman. Theory and History of Literature, vol. 5. Minneapolis: University of Minnesota Press.

- (20I2): The Russian Folktale. Trans. and ed. Sibelan Forrester. Series in Fairy Tale Studies. Detroit: Wayne State University.

Pujol, Josep M. (2013): Three Selected Papers on Catalan Folklore: Traditional Literature and Ethnopoetics; Introduction to a History of Folklores; Extraordinary Stories, Urban Legends. Eds. Carme OrIOL and Emili SAMPER. Tarragona: Publicacions URV. Electronic version <http://publicacionsurv.cat/llibres-digitals/biblioteca-digital/ item/4I9-three-selected-papers-on-catalan-folklore> [last access: July 20I4]

RAGLAN, Lord (I946): "The Scope of Folklore". Folklore no. 57: 98-IO5.

RIEHL, Wilhelm Heinrich (I859): "Die Volkskunde als Wissenschaft." In Culturstudien aus drei Jahrhunderten. Stuttgart: J. G. Cotta, p. 205-229. [Reprinted in Gerhard LuTz (ed.): Volkskunde: Ein Handbuch zur Geschichte ihrer Probleme. Berlin: Erich Schmidt, I958.]

ROPE, Jonathan (2007): “Thoms and the Unachieved 'Folk-Lore of England"”. Folklore vol. II8: 203-2I6. 
Russell, Ian; David ATKINSON (eds.) (2004): Folk Song: Tradition, Revival, and ReCreation. The Elphinstone Insitute Occasional Publications 3. Aberdeen: University of Aberdeen.

SHILS, Edward (198I): Tradition. Chicago: The University of Chicago Press.

Simpson, George Eaton (I973): Melville J. Herskovits. Leaders of Modern Anthropology Series. New York: Columbia University Press.

SMITH, Lllewellyn M. (director and producer) (2009): Herskovits at the Heart of Blackness [videorecording]. Berkeley, CA: California Newsreel.

SMith, Marian A. (I947): "Thoms, «Folk-Lore» and the Folklore Centenary". The Journal of American Folklore no. 60: 4I7-420.

- (I959): "The Importance of Folklore Studies to Anthropology". Folklore no. 70: 3003I 2 .

STOCKING, Jr. George W. (1965): “On the Limits of 'Presentism' and 'Historicism' in the Historiography of the Behavioral Sciences". Journal of the History of the Behavioral Sciences no. I: 2II-2I8.

SzWED, John F. (20IO): Alan Lomax: the Man who Recorded the World. New York: Viking Penguin.

TAYLOR, Archer (I946): “The Problems of Folklore”. Journal of American Folklore no. 59: IOI-IO7.

- (I952): “The Place of Folklore”. PMLA no. 67: 59-66.

TENDLER, Joseph (2013): Opponents of the Annales School. New York: Palgrave Macmillan.

Thompson, Stith (ed.) (1953): Four Symposia On Folklore. Held at the Midcentury International Folklore Conference Indiana University, July 2I-August 4, I950. Indiana University Publications Folklore Series No. 8. Bloomington: Indiana University Press.

Thoms, William [Ambrose Merton] (I846): "Folklore". The Athenaeum no. 982 (August 22, I846): 862-863. [Reprinted in Alan Dundes (ed.): The Study of Folklore. Englewood Cliffs, N. J.: Prentice-Hall, p.4-6; “'Folk-Lore,' from «The Athenæum» August 22, I846." Journal of Folklore Research no. 33 (I996):I87-I89.]

TYLOR, Edward Burnett (I958): The Origins of Culture. New York: Harper \& Brothers. [Originally published as chapters I-X of Primitive Culture. London: John Murray, I87I.]

UTLEY, Francis Lee (1958): "The Study of Folk Literature: Its Scope and Use". The Journal of American Folklore no. 7I: I39-I48.

— (I96I): "Folk Literature: An Operational Definition". Journal of American Folklore no. 74: I93-206.

Watson, Stephen H. (1997): Tradition(s): Refiguring Community and Virtue in Classical German Thought. Bloomington: Indiana University Press.

Weber, Max (I947): The Theory of Social and Economic Organization. Trans. A. M. Henderson and Talcott PARSONS. New York: The Free Press.

- (I949): Max Weber on The Methodology of the Social Sciences. Translated by Edward A. SHILS and Henry A. Finch. Glencoe, Ill.: Free Press.

WelsCH, Roger (1968): "A Note on Definitions". Journal of American Folklore no. 8I: 262-264.

- (2012): Embracing Fry Bread: Confessions of a Wannabe. Lincoln: University of Nebraska Press.

Wilgus, D. K. (I973): “The Text is the Thing”. Journal of American Folklore no. 86: 24I252.

ZumWALT, Rosemary Lévy (I988): American Folklore Scholarship: A Dialogue of Dissent. Bloomington: Indiana University Press. 